\title{
共重合ポリアミドのブロック構造に及ぼす界面重縮合 溶媒の影響
}

（受付1973年 4 月19日・掲載決定1973年 6 月20日）

清造 剛*1 ・ 馬場 巧*1 ・西川恵清*1

\begin{abstract}
要 旨 テトラクロルエタンとテトラクロルエチレンとの混合溶媒を用いて，界面重縮合法によ クナイロン 66一610 系の等モル割合の共重合体を合成した。また 9 種の溶媒を用いて，界面重縮合 法によりナイロン 26-210 系およびナイロン210-610系の等モル割合の共重合体を合成した。その 結果，ナイロン 66-610 系ではブロック構造と溶媒の混合組成との間に相関関倸が認められた。ま たナイロン 26-210系は収率, 固有粘度およびナイロン26含量が低く，ブロック構造がナイロン 66 一610系と同様に溶媒によって顕著に相違し, 一方ナイロン210-610采は収率, 固有粘度拈よびナ イロン 610 含量が高く，ブロック構造が溶媒によってほとんど影響されないことが判明した。そし てこれらの挙動が, 酸クロリドの加水分解速度, ジアミンの分配率すなわちジアミンの有機溶媒へ の拡散速度，および反応の選択性に基ついて説明できることを示した。
\end{abstract}

\section{1. 緒言}

前報1)で，ナイロン 66-610 系共重合体を 9 種の溶媒 を用いて界面共重縮合法により合成し, 生成物の構造が ランダム共重合体に近いものから，連鎖長のかなり長い と推定されるブロック共重合体まで, 溶媒の種類によっ て広範囲に変化することを見いだした。またテトラクロ ルエタンとテトラクロルエチレンの両溶媒系について, 共重合組成を変化させて検討したところ，どの組成にお いても両系のブロック構造が顕著に相違することが認め られた。

そこで本研究では，まずナイロン66一610系につい て,ブロック共重合性の低、溶媒であるテトラクロルエ タンとブロック共重合性の高、溶媒であるテトラクロル エチレンとの混合溶媒を用い，溶媒の混合組成によって 生成物の構造がどのように影響されるかについて検討し た。

つぎに共重合成分の組合せを変化させた采，すなわち ナイロン26一210系扰よびナイロン210-610系について, 前報1)のナイロン 66 - 610 系で用いた 9 種の溶媒を供試 して同様に共重合を行ない，共重合成分の種類とブロッ ク共重合構造との関連について検討した。

\section{2. 実 験 法}

\section{1 単量体の調製}

アジピン酸クロリド，セバシン酸クロリドの合成と精

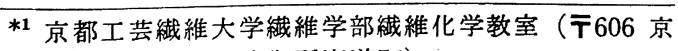
都市左京区松ヶ崎御所海道町)
製，およびへ、ササチレンジアミンの精製は，前報》の 2.1 亿記載した方法によった。エチレンジアミンの精製 もへキサメチレンジアミンと同様の方法によった。

\section{2 溶媒の精製}

前報1 の 2.2 に記載した方法で行なった。

\section{3 界面重縮合法}

前報1)の 2.3 亿記載した方法を用いた。

\section{4 重合体の分析法}

前報1)の 2.4 亿記載した方法で行なった。

\section{3. 結果と考察}

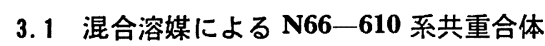

アジピン酸クロリドとセバシン酸クロリドのモル比を $1 ： 1$ に固定し, 溶媒のテトラクロルエタンとテトラク ロルエチレンの混合体積割合を $10 \%$ ずつ変化させた 9 種 の混合溶媒について，2.3の方法により界面共重縮合を 行なった。

得られた共重合物の収率, 固有粘度, および前報 ${ }^{1)} の$ 3.1.2 の IR による組成分析法により求めた共重合物中 のN66の含量を Table 1 に示す。なお, 単独溶媒で得ら れた前報1)のデータも併記して示した。溶液粘度は, そ れぞれの単独溶媒での差を反映して, テトラクロルエタ ンの量が多い場合のほうが若干低い傾向が認められる。 またN66の含量も, 単独溶媒での值と同じくすべて50\% 以下であるが，混合組成が 1：1 に近くなるとさらに減 少する傾向が認められる。

共重合物の DTA 曲線は，N610成分およびN66成分 の結晶の融解に対応して 2 個の吸熱ピークが認められる 
Table 1. Properties of nylon 66-610 copolymers prepared in mixed solvent of tetrachloroethane and tetrachloroethylene.

\begin{tabular}{c|c|c|c}
\hline $\begin{array}{c}\text { Volume \% of } \\
\text { tetrachloroethane }\end{array}$ & $\begin{array}{c}\text { Yield } \\
(\%)\end{array}$ & $\begin{array}{c}{[\eta]} \\
(\mathrm{d} l / \mathrm{g})\end{array}$ & $\begin{array}{c}\text { N66 content } \\
(\mathrm{mol} \%)\end{array}$ \\
\hline 0 & 58 & 1.40 & 46 \\
10 & 42 & 1.16 & 35 \\
20 & 48 & 1.60 & 36 \\
30 & 48 & 1.20 & 39 \\
40 & 43 & 0.92 & 35 \\
50 & 44 & 1.18 & 30 \\
60 & 42 & 0.83 & 35 \\
70 & 43 & 0.91 & 36 \\
80 & 56 & 0.97 & 45 \\
90 & 50 & 1.05 & 48 \\
100 & 60 & 1.03 & 43 \\
\hline
\end{tabular}

がそれぞれのピーク值から求めた融点を溶媒の混合組 成に対してplotして Fig. 1 に示す。テトラクロルエタン の量が増すと融点は両成分とも降下する傾向にはある が，単独溶媒での值間を結んだ直線から上にずれる傾向 がテトラクロルェタン量の多、組成の溶媒で認められ る。融点は生成物中の両成分のブロック連鎖長の尺度と みなせるので，この融点一混合組成の挙動からみると， ブロック共重合性は溶媒の混合組成とはかならずしも直 線関係をもたないように思える。しかし，混合溶媒系の 融点はいずれも両笚独溶媒の融点の間に存在しており, Table 1 の溶液粘度や N66含量の変動などによる融点へ の影響を考虑に入れるならば，やはり溶媒の混合組成と ブロック共重合性との間には相関関係があるとみるのが 妥当のようである。したがって, 混合溶媒を用いること によって共重合体のブロック鎖長の制御がある程度可能



O: N610 component, : N66 component

Fig. 1. Melting point of nylon 66-610 copolymers prepared in mixed solvent of tetrachloroethane and tetrachloroethylene.
であることが示唆される。なお，融点一溶媒組成関係の plot が，加成性を仮定して引いた直線から偏倚を示した 原因として，溶媒間の相互作用の寄与も考慮する必要が あろう。

\section{$3.2 \mathrm{~N} 26$ - 210 系共重合体}

N66一610 系 ${ }^{1)}$ で認められた溶媒の種類によるブロッ ク共重合性の差異の原因が，単量体の反応性，拡散速度， 加水分解速度などのどの因子に起因するものかを検討す るために，まずジアミン成分をエチレンジアミンに変え たN26-210系について，N66一-610系と同様に 9 種の溶 媒を用いて同一の反応条件で界面共重縮合を行なった。

生成物の収率，固有粘度，および IR による組成分析 結果を Table 2 に示打。組成分析はN26の $1280 \mathrm{~cm}^{-1}$ と $\mathrm{N} 210$ の $1240 \mathrm{~cm}^{-1}$ の吸光度を用いて, 前報 ${ }^{1)}$ と同様に 行なった。収率は N66-610系よりも低いが，これはエ

Table 2. Properties of nylon 26-210 copolymers prepared in various solvents.

\begin{tabular}{l|c|c|c}
\hline \multicolumn{1}{c|}{ Solvent } & $\begin{array}{c}\text { Yield } \\
(\%)\end{array}$ & $\begin{array}{c}{[\eta]} \\
(\mathrm{d} l / \mathrm{g})\end{array}$ & $\begin{array}{c}\text { N26 } \\
\text { content } \\
(\mathrm{mol} \%)\end{array}$ \\
\hline Tetrachloroethane & 56 & 0.54 & 30 \\
Chloroform & 59 & 0.38 & 26 \\
Methylene chloride & 60 & 0.52 & 32 \\
Ethylene chloride & 59 & 0.91 & 38 \\
p-Xylene & 54 & 0.41 & 33 \\
o-Dichlorobenzene & 53 & 0.75 & 34 \\
Benzene & 59 & 0.89 & 33 \\
Tetrachloroethylene & 45 & 0.57 & 30 \\
Carbon tetrachloride & 45 & 0.70 & 31 \\
\hline
\end{tabular}



Fig. 2. DTA curves of nylon 26-210 copolymers prepared in various solvents.

高分子化学, Vol. 30, No. 342 (Oct., 1973) 
チレンジアミンがヘキサメチレンジアミンよりも反応性 が悪いためと考えられる。固有粘度がかなり低下してい るのもそのためであろう。組成分析の結果はN26の含量 がかなり少ないが，これはN66一610系の場合と同様に， アジピン酸クロリドの加水分解のしやすさのためであろ う。

Fig. 2 にN26一210系の DTA曲線を示す。なお，N26 およびN210の単独重合体で測定した融点はそれぞれ319 'Cおよび $285^{\circ} \mathrm{C}$ であった。共重合物の DTA 曲線の形状 の変化は, 前報1)の Fig. 3 の N66-610系とほぼ同様で あり， N66一610系でブロック性の大であった下方に挙 げた溶媒のほうが 2 個の融解ピークが明りょうに分離し ており，融解ピークの温度も高い。したがって，この D TA 曲線の挙動から，ブロック構造に及ぼす溶媒の効果 は，N66一-610系と N26-210采ではほぼ同様であり, ジ アミンの反応性の相違はブロック共重合性にあまり影響 しないと考えられる。

\section{$3.3 \mathrm{~N} 210$-610 系共重合体}

つぎに，酸成分をせバシン酸クロリドに固定し，ジア ミン成分にエチレンジアミンとへキサメチレンジアミン を用い， $1: 1$ のモル比で同様に 9 種の溶媒を用いて共 重縮合を行なった。

生成物の収率, 固有粘度, および IR による組成分析 結果を Table 3 に示す。組成分析は N 210 の $1240 \mathrm{~cm}^{-1}$ と $\mathrm{N} 610$ の $1180 \mathrm{~cm}^{-1}$ の吸光度を用いたが，検量曲線の 組成に対する変化が小さかったため精度はあまりよくな い。收率は N66一-610系や N26一-210系よりも高いが， この原因は酸クロリドに加水分解しにくいセバシン酸ク ロリドのみを用いているためであろう。しかし固有粘度 は N66-610采よりも低下しておうり，エチレンジアミン の低反応性が影響したものと思われる。N210の含量が 少ないのもそのためであろう。

Fig. 3 に N210-610系の DTA 曲線を示す。これらの 共重合物の DTA 曲線の形状は, N66-610 系や N26-

Table 3. Properties of nylon $210-610$ copolymers prepared in various solvents.

\begin{tabular}{l|c|c|c}
\hline \multicolumn{1}{c|}{ Solvent } & $\begin{array}{c}\text { Yield } \\
(\%)\end{array}$ & $\begin{array}{c}{[\eta]} \\
(\mathrm{d} l / \mathrm{g})\end{array}$ & $\begin{array}{c}\text { N210 } \\
\text { content } \\
(\mathrm{mol} \%)\end{array}$ \\
\hline Tetrachloroethane & 82 & 0.87 & 28 \\
Chloroform & 88 & 1.22 & 38 \\
Methylene chloride & 87 & 0.65 & 28 \\
Ethylene chloride & 80 & 0.96 & 31 \\
p-Xylene & 73 & 0.98 & 30 \\
o-Dichlorobenzene & 70 & 0.77 & 31 \\
Benzene & 78 & 0.89 & 32 \\
Tetrachloroethylene & 67 & 1.09 & 16 \\
Carbon tetrachloride & 65 & 0.70 & 28 \\
\hline
\end{tabular}

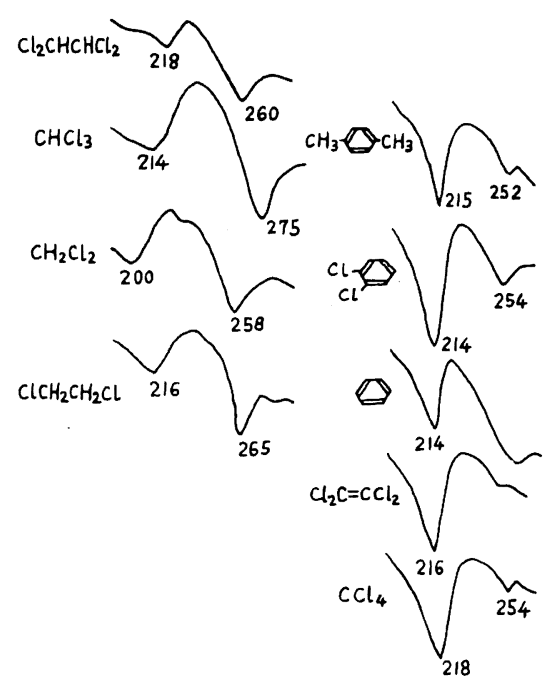

Fig. 3. DTA curves of nylon 210-610 copolymers prepared in various solvents.

210 系と相違していずれも 2 個の融解ピークが明りょう に分離して認められる。また両成分の融点は Table 3 の N210 含量の変動を考虑すればほぼ同じ温度付近に存在 すると考えられる。したがって，N210-610系はいずれ もブロック共重合性の高い構造を有しており，そのブロ ック共重合性は溶媒の種類によってあまり影響されない と推定される。

\section{4 ブロック共重合性とジアミンの分配率}

上記の実験の結果, 溶媒の相違はジアミン成分共重合 系ではあまり影響せず，酸成分共重合系ではジアミンの 種類に関倸なく同様に影響することが判明した。そこで ブロック鎖長に差異を生じた原因として, 酸クロリド成 分の反応性が溶媒によって相違することが挙げられる。 この場合, アジピン酸クロリドとセバシン酸クロリドは いずれも界面重縮合法によって短時間で高分子量の重合 体を生成するから, 両者ともジアミンとの反応速度は非 常に速いと考えられる。また用いた溶媒はそれほど極性 が相違しないため, 酸クロリドの反応性が溶媒の極性効 果によって大きく左右されることは考えにくい。したが って酸クロリドの反応性の相違以外の因子が原因したと 考えるほうが妥当のようである。

界面重縮合反応では, ジアミンが水層から有機溶媒層 中に抬散してそこで酸クロリドと反応寸ることが報告さ れている2。そこで，つぎにジアミンの有機溶媒層への 拡散速度が問題となろう。これに関する情報として, ジ アミンの水と有機溶媒への分配率が挙げられる。Table 4 に Morgan ら ${ }^{2)}$ と木藤ら ${ }^{3)}$ によって測定されたへキサ メチレンジアミンの分配率を示す。Table 4 中の溶媒の 
Table 4. Partition coefficient of hexamethylenediamine $\left(\mathrm{C}_{\mathrm{H}_{2} \mathrm{O}} / \mathrm{C}_{\text {solvent }}\right)$.

\begin{tabular}{l|c|c}
\hline \multicolumn{1}{c|}{ Solvent } & Morgan $^{2)}$ & Kifugi $^{3)}$ \\
\hline $\begin{array}{l}\text { Tetrachloroethane } \\
\text { Chloroform }\end{array}$ & 0.70 & 1.03 \\
$\begin{array}{l}\text { Methylene chloride } \\
\text { Ethylene chloride }\end{array}$ & 5.6 & 13.05 \\
$\begin{array}{l}\text { p-Xylene } \\
\text { o-Dichlorobenzene }\end{array}$ & 50 & \\
Benzene & & \\
Tetrachloroethylene & & 43.7 \\
Carbon tetrachloride & 35 & 66.0 \\
\hline
\end{tabular}

記載順序は今までの Table と同じくブロック性の高いも のほど下方に示してあるが，分配率もブロック性の高い ものほど大きくなっている。分配率の大きい溶媒は有機 溶媒中へのジアミンの拡散速度が遅いと考えられるか ら，ジアミンの拡散速度が遅い溶媒ほどブロック鎖長の 長い共重合体を生成したことになる。

この理由として，まずN66-610系ではN66含量が低 いことから，ジアミンの拡散速度が遅いとアジピン酸ク ロリドの加水分解がより進行するため, セバシン酸ク口 リドとジアミンとの反応率が増大し，それだけ N610成 分の鎖長が長くなり，ブロック共重合性が大になるので はないかと考えられる。しかしこの説明によると，ブロ ック共重合性の大きい重合体ほどN66含量が少なくなっ てよいはずである。ところが前報1)の結果や本実験の Table 1 と Fig. 1 の比較から明らかなように, N66含量 と融点の間には一義的な関係は見いだせない。この理由 としては, 短時間の反応により重合を中断しているため, 操作上の実験誤差的因子により収率が変動し, それがN 66含量に影響したためであるとして一応の解採はでき る。しかしこのアジピン酸クロリドの加水分解による説 明では，確率的に N610成分の連鎖が長くなることは一 态説明できるとしても，N66成分の連鎖が長くなること の説明がつかない。

そこで，ブロック共重合体生成の理由として，つぎに 酸クロリドの反応の選択性を考えてみた。すなわち，同 種の酸クロリド間で反応が優先的に起こると仮定する。 この根抛は，同種の分子は異種の分子よりも親和性がよ
いことにある。そこで，反応によりまず生成する 2 量体 や 3 量体は, 水との界面の溶媒中で同種のもの同士が接 近あるいは会合しやすく，そのため问種の連鎖が選択的 に結合し，それらが固体状に析壮する過程で異種分子の 連鎖と結合してブロック共重合体が生成すると考える。 この場合, ジアミンの分配率が小さく拡散速度が速い溶 媒でブロック連鎖が短くなったことから，反応が急速に 起こると選択性が作用しにくくなると考えられる。

N26一210系でも同様であるが，エチレンジアミンは ヘキサメチレンジアミンよりもメチレン鎖の数が少ない ため水との親和性が大きく，したがって用いた疎水性の 大きい溶媒中ではより拡散速度が遅くなると推定され る。N26-210 系で収率が低く，N26含量が少なく，固 有粘度が低くなったのは, エチレンジアミンり拡散速度 が遅く,それだけアジピン酸クロリドの加水分解が進行 したことによるものである。前節 (3.2 と 3.3) では, エ チレンジアミンはへキサメチレンジアミンよりも反応性 が悪いと表現したが，その低反応性の原因は反応の場へ の拡散の遅さによるものであろう。

最後に，N210-610系でいずれもブロック性が大き く，その程度が溶媒によってあまり影響されなかった理 由であるが，この場合は N210含量が低いことから，エ チレンジアミンがへキサメチレンジアミンよりも拡散速 度が遅いことがブロック性の原因であると考えられる。 その場合, 拡散速度の差が反応の選択性よりも優先した ため, 溶媒による拡散速度の相違があまりブロック性に 影響しなかったと推定される。なお，この系の収率や固 有粘度が比較的高いのはセバシン酸クロリドの加水分解 速度が遅いことによるものである。

付記 本研究にご援助をいただいた本学の内海暢生教 授ならびに松本喜代一助手に感謝します。

\section{文献}

1) 清造 剛, 釜谷彰郎: 高分子化学, 28, 279 (1971)

2) P. W. Morgan, S. L. Kwolek: J. Polym. Sci., 40, 299 (1959)

3）木藤武利，三上隆三，吉原秀夫，林 滋啓，平 尾一郎：日化会第 24 年会講演予稿集, 2094 (1971) 